\title{
微生物のアスパラギン酸誘導体変換酵素に 関する新たな展開
}

\author{
和田 大 \\ 北海道大学大学院農学研究科
}

アミノ酸変換酵素, 特にラセマー ゼ, トランスフェラーゼ, $\beta$ リリーゼ などのピリドキサールリン酸 (PLP) 依存性酵素には長い研究の歴史があ る.アミノ酸は生命に必須な物質であ るため, PLP 依存性酵素も古細菌か ら高等動物に至るすべての生物に存在 している.それだけに, 反応機構や立 体構造に関しても多くのデータが蓄積 され，もはや「やり尽くされた」感が ある. 実際, 新規な酵素の報告も最近 は少なくなっている。

しかし, タンパク質を構成している 20 種類のアミノ酸以外のアミノ酸を 変換する酵素に注目すると, まだまだ 研究の進んでいないものも多い.たと えばアスパラギン酸誘導体である 3ヒドロキシアスパラギン酸に作用す る微生物酵素については, 1960 年代
に 2 つの酵素, ヒドロキシアスパラギ ン酸デヒドラターゼ(1) とヒドロキシ アスパラギン酸アルドラーゼ(2) が報 告されている. 両酵素ともグリオキシ ル酸を単一炭素源として Micrococcus denitrificans を培養するという特殊 な条件で誘導される.これら 2 種の酵 素は, EC 番号が付与されているもの の完全精製の報告はなく, コードする 遺伝子も単離されていなかった. 3-ヒ ドロキシアスパラギン酸はアスパラギ ン酸の-OH アナログであり, 天然界 ではペプチド性抗生物質の構成成分な どとして見いだされる. 図 1 に示すよ うに分子中に 2 個の不斉炭素を有し， 4 つの光学異性体が存在する.

最近, Paracoccus denitrificans (Micrococcus denitrificans より改 名）IFO13301株からヒドロキシアス
パラギン酸アルドラーゼが精製され， 遺伝子がクローニングされた ${ }^{(3)}$. 本酵 素は分子量 43,000であり, D 体の七 ドロキシアスパラギン酸に作用する (図1(a)). しかし，D-スレオ体と Dエリスロ体の区別はできない. ヒドロ キシアスパラギン酸以外に, スレオニ ン，フェニルセリンなどの $\beta$-ヒドロ キシアミノ酸の $\mathrm{D}$ 体も基質となる。ま た, $\mathrm{Mn}^{2+}, \mathrm{Mg}^{2+}, \mathrm{Co}^{2+}$ などの 2 価金 属で活性化される，本酵素をコードす る DNA は $1,161 \mathrm{bp}$ からなり, Dース

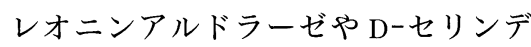
ヒドラターゼと相同性を示す.

また，ヒドロキシアスパラギン酸デ ヒドラターゼについても, 最近筆者ら によって再発見されている(4). ヒドロ キシアスパラギン酸を単一炭素源とし て，新たにスクリーニングした土壌細

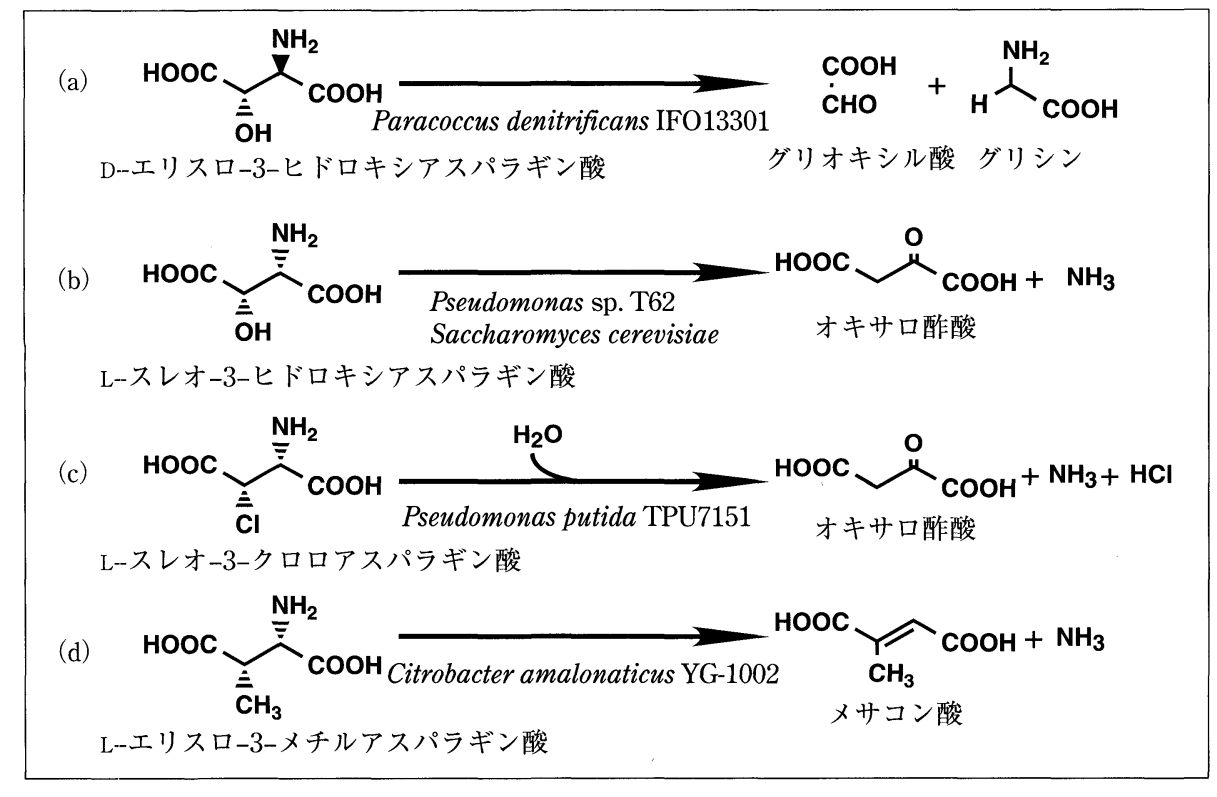

図 1 微生物に見いだされた各種 アスパラギン酸誘導体変換酵素

(a) D-3-ヒドロキシアスパラギン酸 アルドラーゼ，(b) L-スレオ-3-ヒド ロキシアスパラギン酸デヒドラター ゼ，(c) L-スレオ-3-クロロアスパラ ギン酸リアーゼ，(d) メチルアスパル ターゼ 
菌Pseudomonas sp. T62 より, ヒド ロキシアスパラギン酸デヒドラターゼ が電気泳動的にほぼ均一に精製され た. 本酵素はヒドロキシアスパラギン 酸を単一炭素源として培養した場合に 誘導され，グリオキシル酸単一炭素源 という条件は必要としない. 分子量は SDS-PAGE上で約 39,000 であり, L-スレオ体のヒドロキシアスパラギ ン酸に特異的に作用し, エリスロ体の ヒドロキシアスパラギン酸やスレオニ ン，セリンなどは基質とならない(図 1(b)). 本酵素も $\mathrm{Mn}^{2+}, \mathrm{Mg}^{2+}, \mathrm{Co}^{2+}$ などの 2 価金属で活性化される，遺伝 子はクローニングされていない. ヒド ロキシアスパラギン酸アルドラーゼ, ヒドロキシアスパラギン酸デヒドラタ ーゼともにPLP依存型酵素である。

本酵素の $\mathrm{N}$ 末端アミノ酸配列は, 酵母 Saccharomyces cerevisiae のア ミノトランスフェラーゼと推定され る (putative aminotransferase) YKL218c 遺伝子産物の $\mathrm{N}$ 末端部分 と有意な相同性を示すことから, 真 核生物であるS. cerevisiaeにも七 ドロキシアスパラギン酸デヒドラ ターゼの存在する可能性が示された. そこで, データベース情報をもとに S. cerevisiae のゲノムから PCR で YKL218 c を釣り上げて大腸菌内で強 制的に発現させたところ, YKL218 c 遺伝子産物は大腸菌内で不溶化しやす

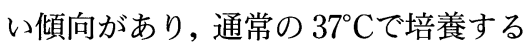
と, 大腸菌細胞抽出液にはごく低い活

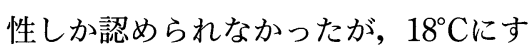
ると高いヒドロキシアスパラギン酸デ ヒドラターゼ活性が検出された.

S. cerevisiae の酵素は分子量約 39,500であり, やはり L-スレオ体の ヒドロキシアスパラギン酸に特異的で ある(5). Pseudomonas 属細菌だけで なくS. cerevisiae にもヒドロキシア
スパラギン酸分解酵素が存在している 理由は何か？ 環境中で微生物がヒド ロキシアスパラギン酸に出会う確率 は，我々が考えているよりも高いのか もしれない.

S. cerevisiae に見いだされた酵素 に関しては, YKL218 c 遺伝子の破壊 実験も行なわれ(5)，破壊株はヒドロキ シアスパラギン酸により生育が阻害さ れた。生育阻害は培地へのアスパラギ ン酸の添加で回復することから, $S$. cerevisiae 内ではヒドロキシアスパラ ギン酸はアスパラギン酸のアナログと して作用し毒性を発揮するものと考え られる. 以前, 本酵素はその一次構造 の相同性から，セリンラセマーゼでは ないかと考えられていたが, 活性は検 出されず, 現在ではデータベースから もセリンラセマーゼホモログのアノテ ーションは削除されている。一次構造 だけからのアノテーションの不正確 さ，また基質特異性の予想の難しさを 示す一例ではないだろうか.これら 2 つの酵素では残念ながら逆反応は進 行せず, 光学活性なアスパラギン酸 誘導体の合成に直接利用することは 難しい. また，クロロアスパラギン酸 に作用して， $\beta$-脱離を触媒する PLP 依存型酵素も報告されており ${ }^{(6)}$ (図 1(c))，ヒドロキシアスパラギン酸デ ヒドラターゼと類似の酵素と考えられ る.

一方，グルタミン酸の嫌気代謝中間 体であるメチルアスパラギン酸を分解 するメチルアスパルターゼに関して は, 以前は絶対嫌気性の Clostridium 属細菌にしか存在が報告されていなか ったが, 最近, 通性嫌気性菌である Citrobacterにもその存在が見いださ $れ^{(7)}($ 図 $1(\mathrm{~d}))$, 一次構造のみならず $\mathrm{X}$ 線結晶構造解析も行なわれ, 反応 機構も推定されている ${ }^{(8)}$. 反応様式は
PLP 依存型 $\beta$-リアーゼとは異なり, 補酵素も要求しない.メサコン酸から の逆反応も進行するので, 光学活性な 各種アスパラギン酸誘導体の合成に利 用できる、二重結合への立体選択的な 付加反応で一気に 2 個の不斉中心を導 入できるので, 物質生産の観点から有 用な酵素である。

\section{$*$}

研究の歴史の長いアミノ酸変換酵素 であるが，このように一般的なアミノ 酸にこだわらずに探索すれば，まだユ ニークな酵素も存在すると思われる. またバイオインフォマティクスの発達 した現在でも, 酵素のアミノ酸配列か らその基質特異性を正確に予想するの は難しい. データベース中に大量に登 録されている “putative aminotransferase”の中にも, 新規な反応を触媒 する酵素がまだ存在するのではないだ ろうか.

1) R.G. Gibbs \& J.G. Morris : Biochim. Biophys. Acta, 85, 501 (1964).

2) R.G. Gibbs \& J.G. Morris : Biochem. J., 97, 547 (1965).

3) J.Q. Liu, T. Dairi, N. Itoh, M. Kataoka \& S. Shimizu : Appl. Microbiol. Biotechnol., 62, 53 (2003)

4) M. Wada, T. Matsumoto, S. Nakamori, M. Sakamoto, M. Kataoka, J. Q. Liu, N. Itoh, H. Yamada \& S. Shimizu : FEMS Microbiol. Lett., 179, 147 (1999).

5) M. Wada, S. Nakamori \& H. Takagi : FEMS Microbiol. Lett., 225, 189 (2003).

6) Y. Kato \& Y. Asano : Biosci. Biotechnol. Biochem., 65, 435 (2001).

7) Y. Kato \& Y. Asano : Appl. Microbiol. Biotechnol., 50, 468 (1998).

8) C.W. Levy, P.A. Buckley, S. Sedelnikova, Y. Kato, Y. Asano, D.W. Rice, \& P.J. Baker : Structure, 10, 105 (2002). 